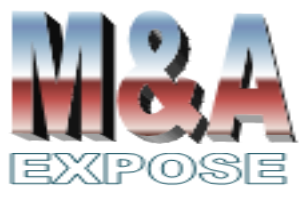

http://jurnal.usahid.ac.id/index .php/accounting
1,2,3Sekolah Tinggi IImu Ekonomi Widya Manggala 1triani129@gmail.com ²yenikuntari@gmail.com

\section{Pengaruh Kepemilikan Saham Publik, Profitabilitas, dan Media terhadap Pengungkapan Tanggung Jawab Sosial Perusahaan}

\author{
Silvia Debora Hitipeuw ${ }^{1}$, Yeni Kuntari² ${ }^{2}$ Triani $^{3}$
}

\section{Abstrak}

Penelitian ini bertujuan untuk menganalisis faktor yang mempengaruhi pengungkapan Corporate Sosial Responsibility (CSR). Faktor-faktor yang diteliti dalam penelitian ini adalah Kepemilikan Saham Publik, Profitabilitas dan Media sebagai variabel independen sedangkan CSR sebagai variabel dependen. Sampelnya adalah perusahaan Properti dan Real Estate yang terdaftar di Bursa Efek Indonesia (BEl) yang menyampaikan laporan keuangan secara konsisten pada 2016-2018. Data yang digunakan dalam penelitian ini adalah data sekunder menggunakan metode Purposive Sampling. Analisis Regresi Linier Berganda digunakan sebagai penganalisis data. Hasil pengujian menunjukkan bahwa Kepemilikan Saham Publik dan Media berpengaruh signifikan terhadap Pengungkapan CSR, sedangkan Profitabilitas tidak memiliki pengaruh yang signifikan terhadap Pengungkapan CSR. Secara simultan Kepemilikan Saham, Profitabilitas dan Media berpengaruh signifikan terhadap Pengungkapan CSR perusahaan Properti dan Real Estat yang terdaftar di Bursa Efek Indonesia untuk periode 2016-2018.

Kata kunci : Kepemilikan Saham Publik, Profitabilitas, Media, CSR.

\section{Abstract}

The purpose of this study was to analyze the factors that affect Corporate Sosial Responsibility Disclosure (CSR). The factors examined in this study are Public Shareholding, Profitability and Media as the independent variables while CSR as the dependent variable. The samples were Property and Real Estate companies listed in Indonesia Stock Exchange (IDX) that submitted financial reports consistently in 2016-2018. The data used in this study were secondary data using the Purposive Sampling method. The Analysis of the data in this study used Multiple Linear Regression analysis. The test results showed that Public Shareholding and Media had significant effect on CSR Disclosure, while Profitability did not have significant effect on CSR Disclosure. Simultaneously Public Shareholding, Profitability and Media had significant effect on CSR Disclosures of Property and Real Estate companies listed in Indonesia Stock Exchange for the period of 2016-2018.

Keywords: Public Shareholding, Profitability, Media, Corporate Sosial Responsibility Disclosure. 


\section{PENDAHULUAN}

Industri property dan real estate di Indonesia saat ini kian menjamur dan berkembang dengan pesatnya. Hal tersebut dibuktikan banyaknya gedung bertingkat dan perumahan di kota maupun di pedesaan atau daerah pinggiran perkotaan, sehingga jalur penghijauan semakin sedikit (Sriayu et al., 2013). Masalah lingkungan dan sosial semakin meningkat karena aktivitas perusahaan, kondisi itu semakin diperparah karena aturan pemerintah yang mengatur pelaporan tanggung jawab sosial bersifat sukarela dalam laporan tahunan perusahaan. Untuk menghadapi permasalahan tersebut, pemerintah mengesahkan Undang-Undang RI No. 40 Tahun 2007 tentang Perseroan Terbatas dengan memasukan peraturan mengenai kewajiban setiap entitas bisnis untuk mengungkapkan tanggung jawab sosial dan lingkungan.

Tercatat adanya growth yang sangat baik dari sisi penjualan sektor property dan real estate. Peningkatan tersebut dipengaruhi oleh aset yang mengalami kenaikan pada tahun 2015 sebesar Rp 167,74 triliun menjadi Rp 197,72 triliun pada tahun 2016, kredit pun mengalami kenaikan pada tahun 2015 sebesar Rp 132,89 triliun menjadi Rp 154,99 triliun pada tahun 2016 (www.mediaindonesia.com). Pro dan kontra terjadi dalam industri property dan real estate, hal tersebut dapat berdampak langsung pada masyarakat yang tinggal di sekitar industri yang melakukan kegiatan pembangunan. Manfaat yang ditimbulkan dari kegiatan industry property dan real estate yaitu menyerap tenaga kerja (mengurangi pengangguran) belum sebanding dengan kerusakan lingkungan yang diakibatkan kegiatan tersebut. Untuk itu diharapkan korporasi dapat menjadi entitas yang mampu memperhatikan kepedulian terhadap lingkungan dan sosial dengan melakukan kontrak sosial dengan masyarakat dan pemerintah setempat agar bisa saling memberdayakan serta sama-sama menikmati manfaat ekonomisnya secara langgeng (Rahayu \& Anisyukurlillah, 2015).

Berbagai penelitian yang terkait dengan pengungkapan tanggung jawab sosial perusahaan menunjukkan keanekaragaman hasil. Rahayu et al., (2015) menunjukkan bahwa kepemilikan saham publik berpengaruh positif terhadap pengungkapan Corporate Social Responsibility (CSR). Indraswari \& Astika (2015) memaparkan hasil yang bertentangan yaitu kepemilikan saham publik tidak berpengaruh terhadap pengungkapan CSR. Selanjutnya Sari (2012) menyatakan variabel profitabilitas berpengaruh positif terhadap pengungkapan CSR. Namun berbeda dengan temuan Wijaya (2012) yang menunjukkan bahwa profitabilitas tidak berpengaruh signifikan terhadap pengungkapan CSR. Kristi (2013) menjelaskan bahwa pengungkapan media berpengaruh signifikan terhadap CSR. Adapun Rahayu \& Anisyukurlillah (2015) menyatakan pengungkapan media tidak berpengaruh terhadap pengungkapan CSR.

Berdasarkan latar belakang di atas, penulis tertarik melakukan penelitian untuk menganalisis pengaruh Kepemilikan Saham Publik, Profitabilitas dan Media terhadap Pengungkapan CSR yang diharapkan dapat berkontribusi dalam kajian akademik. Penelitian ini meneliti perusahaan properti dan real estate yang terdaftar di BEI tahun 2011-2013. Perusahaan property dan real estate dipilih dalam penelitian ini karena telah banyak penelitian terdahulu yang melakukan penelitian yang terkait dengan Corporate Sosial Responsibility (CSR) namun hasil penelitian masih beragam. 
Pengaruh Kepemilikan Saham Publik, Profitabilitas, dan ...

Silvia Debora Hitipeuw, Yeni Kuntari, Triani

\section{TINJAUAN PUSTAKA}

Teori Stakeholder. Stakeholder merupakan hal yang berhubungan erat dengan tanggung jawab sosial. Stakeholder merupakan pihak-pihak yang berhubungan dan dapat mempengaruhi atau dipengaruhi oleh proses pencapaian tujuan suatu organisasi. Ghozali \& Chariri (2007) memaparkan bahwa keberadaan suatu perusahaan sangat dipengaruhi oleh dukungan yang diberikan oleh stakeholder perusahaan tersebut. Perusahaan bukanlah entitas yang hanya beroperasi untuk kepentingan sendiri, dan untuk mendapatkan dukungan dari stakeholdemya perusahaan kemudian memberikan manfaat bagi para stakeholdemya.

Teori Legitimasi. Teori legitimasi telah digunakan dalam kajian akuntansi untuk mengembangkan teori penggungkapan tanggung jawab sosial perusahaan. Rahayu et al. (2015) mengutarakan bahwa teori legitimasi didasarkan pada pengertian kontrak sosial dasar pemikiran teori ini adalah perusahaan akan terus berlanjut keberadaannya jika masyarakat menyadari bahwa organisasi beroperasi untuk sistem nilai yang sepadan dengan nilai masyarakat itu sendiri.

Corporate Sosial Responsibility. Internasional Organization for Standardization (ISO) 26000 (Suharto, 2010) menyatakan tanggung jawab sosial perusahaan adalah tanggung jawab sebuah organisasi terhadap dampak-dampak dari keputusan-keputusan dan kegiatan-kegiatannya pada masyarakat dan lingkungan yang diwujudkan dalam bentuk perilaku transparan dan etis yang sejalan dengan pembangunan berkelanjutan termasuk kesehatan dan kesejahteraan masyarakat; mempertimbangkan harapan pemangku kepentingan, sejalan dengan hukum yang ditetapkan dan norma-norma perilaku internasional; serta integrasi dengan organisasi secara menyeluruh. Praktik bisnis pada masa sekarang ini tidak terbatas pada tujuan pembuatan profit tetapi juga meliputi elemen CSR dan akuntabilitas (Ghozali, 2007).

Kepemilikan Saham Publik. Kepemilikan publik merupakan presentase saham yang dimiliki oleh publik. Presentase kepemilikan publik di sebuah perusahaan dapat memonitoring perusahaan adanya kepemilikan publik yang besar. Dengan adanya kepemilikan publik yang besar diharapkan perusahaan lebih transparan dalam pengungkapan informasi mengenai perusahaan (Franita, 2018).

Profitabilitas. Rasio profitabilitas yang digunakan dalam penelitian ini yaitu Return on Assets (Hery, 2017). ROA adalah rasio yang mampu menggambarkan kemampuan peusahaan dalam menghasilkan laba melalui semua kemampuan asset perusahaan.

Pengungkapan Media. Internet merupakan jaringan global dan sebuah situs web dapat menjadi media promosi yang sangat efektif serta alat bantu pemasaran yang tangguh. Banyak perusahaan membangun situs web yang dirancang dengan tujuan untuk membangun persepsi perusahaan bersangkutan terhadap khalayaknya (Morissan, 2015). Menurut Harmoni (2010) media adalah sumber daya pada informasi lingkungan. Pengkomunikasian CSR melalui media akan meningkatkan reputasi perusahaan di mata masyarakat. Sari (2012) menyatakan bahwa perusahaan dapat mengungkapkan aktivitas CSR melalui media, salah satunya melalui internet (web) merupakan media yang efektif karena pemakai internet yang mulai meningkat.

Kebaruan dalam penelitian ini adalah memasukan variabel media sebagai salah satu faktor yang mempengaruhi pengungkapan CSR karena kegiatan CSR sebagai kewajiban 
perusahaan yang menjadi trend global. Hal tersebut sesuai pendapat Gosslimh \& Vocht (2007) dalam Karina \& Etna (2013) yang mengutarakan CSR dapat dipandang sebagai kewajiban dunia bisnis untuk menjadi akuntabel terhadap seluruh stakeholdemya bukan hanya terhadap tujuan keuangan semata. Kesadaran akan pentingnya pengimplementasian CSR menjadi tren global, seiring dengan maraknya keperdulian masyarakat global terhadap produk-produk yang ramah lingkungan dan diproduksi dengan memperhatikan lingkungan dan social. Media terkait jejaring internet merupakan jaringan global dan sebuah situs web dapat menjadi media promosi yang sangat efektif serta alat bantu pemasaran yang tangguh.

Hipotesis. Kepemilikan publik merupakan presentase saham yang dimiliki oleh publik. Persentase kepemilikan publik di suatu perusahaan dapat memonitoring perusahaan. Dengan adanya kepemilikan publik yang besar, maka semakin besar pula pengawasan yang dilakukan dan perusahaan juga harus dapat mengungkapkan seluruh informasi yang diperlukan oleh pemegang saham (Franita, 2018). A'inun \& Rakhman (2005) mengemukakan semakin besar kepemilikan yang dimiliki oleh publik, maka publik pun ingin mengetahui mengenai informasi tentang perusahaan sehingga makin banyak butir yang diungkapkan melalui laporan keuangan. Investor ingin memperoleh informasi yang luas tentang tempat mereka berinvestasi serta dapat mengawasi kegiatan manajemen agar kepentingan perusahaan terpenuhi. Perusahaan yang kepemilikan saham publiknya tinggi menunjukkan bahwa perusahaan dianggap mampu beroperasi dan memberikan deviden yang sesuai kepada masyarakat sehingga cenderung akan mengungkapkan informasi sosial yang lebih luas (Badjuri, 2012; Rahayu et al., 2015). Jadi kepemilikan saham publik berpengaruh positif terhadap pengungkapan CSR. Dengan demikian, hipotesis yang diajukan adalah sebagai berikut:

H1 : Kepemilikan Saham Publik berpengaruh positif terhadap pengungkapan CSR pada Perusahaan Property dan Real Estate.

Rasio profitabilitas merupakan rasio yang menggambarkan kemampuan perusahaan dalam menghasilkan laba melalui semua kemampuan dan sumber daya yang dimilikinya, yaitu yang berasal dari kegiatan penjualan, penggunaan aset, maupun penggunaan modal. Penelitian menunjukkan hasil bahwa perusahaan dengan profitabilitas yang tinggi akan mengungkapkan CSR yang tinggi pula (Alnajjar 2000; Haniffa \& Cooke 2005; Gamerschlag et al. 2011; Giannarakis 2014; Muttakin et al. 2015). Studi empiris oleh Haniffa \& Cooke (2005) menyatakan bahwa perusahaan yang menguntungkan menyediakan informasi CSR untuk melegitimasi masyarakat setempat di sekitar perusahaan beroperasi. Lebih lanjut, Haniffa \& Cooke (2005) mengemukakan hubungan positif antara profitabilitas dan tingkat pengungkapan CSR karena adanya kebebasan dan fleksibilitas manajemen untuk menerbitkan inisiatif CSR yang lebih tinggi kepada para pemegang saham. Semakin besar profitabilitas perusahaan maka semakin luas pengungkapan CSR. Perolehan laba yang semakin besar akan membuat perusahaan mengungkapkan informasi sosial yang lebih luas (Rahayu et al., 2015). Jadi profitabilitas berpengaruh positif terhadap pengungkapan CSR. Dengan demikian, hipotesis yang diajukan adalah sebagai berikut:

$\mathrm{H}_{2}$ : Profitabilitas berpengaruh positif terhadap pengungkapan CSR pada Perusahaan Property dan Real Estate. 
Media adalah sumber daya pada informasi lingkungan, pengkomunikasian CSR melalui media akan meningkatkan reputasi perusahaan di mata masyarakat (Harmoni, 2010). Media menyediakan informasi bagi perusahaan dan dapat pula sebagai alat publikasi serta sosialisasi yang digunakan oleh perusahaan. Dalam pengkomunikasian laporan sosial dan lingkungan melalui media akan meningkatkan reputasi perusahaan di mata masyarakat (Nur \& Priantinah, 2012) dalam Julekhah \& Evi Rahmawati (2019). Informasi lingkungan yang baik dan positif akan memberikan keyakinan dan pengakuan baik dari stakeholders. Jadi media berpengaruh positif terhadap pengungkapan CSR. Dengan demikian, hipotesis yang diajukan adalah sebagai berikut:

$\mathrm{H}_{3}$ : Media berpengaruh positif terhadap pengungkapan CSR pada Perusahaan Property dan Real Estate.

\section{METODE PENELITIAN}

Jenis data dalam penelitian ini adalah data dokumenter yaitu jenis data penelitian yang memuat apa dan kapan sesuatu kejadian atau transaksi, serta siapa saja yang terlibat dalam suatu kejadian. Sumber data penelitian ini adalah data sekunder yang diperoleh dari data internal perusahaan property dan real estate yang terdaftar di Bursa Efek Indonesia (BEI) tahun 2016-2018.

CSR adalah suatu proses pengukuran, pencatatan, pelaporan, dan pengungkapan informasi terkait dampak sosial dan lingkungan dari tindakan-tindakan ekonomi perusahaan terhadap kelompok-kelompok tertentu dalam masyarakat atau yang menjadi stakeholder perusahaan (Lako, 2011). Dalam penelitian ini, CSR pada perusahaan property dan real estate dinyatakan dalam variable dummy, dengan pengukuran 1 (satu) jika item i diungkapkan dan 0 (nol) jika item i tidak diungkapkan.

Kepemilikan publik merupakan persentase saham yang dimiliki oleh publik. Persentase kepemilikan publik yang ada di sebuah perusahaan dapat memonitor perusahaan. Kepemilikan publik yang besar akan mendorong semakin banyak pula pengawasan yang dilakukan, dan perusahaan juga harus dapat mengungkapkan seluruh informasi yang diperlukan oleh pemegang saham (Franita, 2018).

$$
\mathrm{KSP}=\frac{\text { Jumlah Kepemilikan Lembar Saham Publik }}{\text { Total Lembar Saham Perusahaan }} \times 100 \%
$$

Kasmir (2016) menyatakan bahwa profitabilitas merupakan rasio untuk menilai kemampuan perusahaan dalam mencari keuntungan. Laba tersebut didapat dari penjualan dan pendapatan investasi, sehingga penggunaan rasio ini akan menunjukan efisiensi perusahaan.

$$
\text { ROA }=\frac{\text { Laba Bersih Setelah Pajak }}{\text { Total Aktiva }}
$$

Media adalah sumber daya pada informasi lingkungan pengkomunikasian CSR melalui media akan meningkatkan reputasi perusahaan di mata masyarakat (Harmoni, 2010). Penelitian ini mengukur media melalui website dengan variabel dummy, yaitu dengan 
memberikan nilai 1 (satu) untuk perusahaan yang mengungkapkan kegiatan CSR di media website dan 0 (nol) untuk perusahaan yang tidak mengungkapkan kegiatan CSR di media website. Dimensi atau indikator media:

- $Y a=1 \quad$ : perusahaan yang mengungkapkan kegiatan CSR di media website.

- Tidak = 0 : perusahaan yang tidak mengungkapkan kegiatan CSR di media website.

Teknik pengambilan sampel pada penelitian ini adalah purposive sampling dengan jenis metode judgement sampling yaitu tipe pemilihan sampel secara tidak acak yang informasinya diperoleh dengan menggunakan perimbangan tertentu (Indriantoro dan Supomo, 2002). Kriteria dalam penelitian ini antara lain :

Tabel 1. Sampel Perusahaan Property dan Real Estate Periode 2016-2018

\begin{tabular}{|c|l|c|c|c|}
\hline No. & \multicolumn{1}{|c|}{ Kriteria Pengambilan Sampel } & 2016 & 2017 & 2018 \\
\hline 1. & $\begin{array}{l}\text { Perusahaan Property dan Real Estate yang } \\
\text { mempublikasikan Laporan Keuangan berturut-turut tahun } \\
2016-2018\end{array}$ & 48 & 48 \\
\hline 2. & $\begin{array}{l}\text { Perusahaan Property dan Real Estate yang tidak } \\
\text { mengeluarkan Laporan Keuangan secara kontinyu yang } \\
\text { berisi pengungkapan CSR 2016-2018 }\end{array}$ & $(18)$ & $(18)$ & $(18)$ \\
\hline & Jumlah Data & 30 & 30 & 30 \\
\hline
\end{tabular}

Sumber : data diolah, 2019.

Teknik pengumpulan data dalam penelitian ini adalah teknik pengumpulan data dari basis data untuk mendapatkan data arsip sekunder dengan cara menelusuri laporan tahunan dan informasi perusahaan yang terpilih menjadi sampel.

Statistik deskriptif memberikan gambaran atau deskripsi suatu data yang dilihat dari nilai rata-rata, standar deviasi, maksimum dan minimum (Ghozali, 2011). Selanjutnya, fokus penelitian ini menganalisis pengungkapan CSR yang dikaitkan dengan kepemilikan saham publik, profitabilitas dan media,. Penelitian ini menggunakan model regresi linier berganda. Adapun bentuk umum persamaan regresi linier berganda adalah sebagai berikut:

$\hat{Y}=b_{0}+b_{1} X_{1}+b_{2} X_{2}+b_{3} X_{3}$

$\hat{Y} \quad:$ : Corporate Sosial Responsibility Index $\mathrm{j}$

$\mathrm{b}_{0} \quad$ : Konstanta

$\mathrm{b}_{1}, \mathrm{~b}_{2}, \mathrm{~b}_{3} \quad$ : Koefisien Regresi

$\mathrm{X}_{1} \quad$ : Kepemilikan Saham Publik

$\mathrm{X}_{2} \quad$ : Profitabilitas

$\mathrm{X}_{3} \quad$ : Pengungkapan Media

\section{HASIL DAN PEMBAHASAN}

Uji statistik deskriptif variabel kepemilikan saham publik menunjukkan rata-rata sebesar 30,6033. Hal ini berarti bahwa rata-rata perusahaan sampel memiliki saham yang dimiliki oleh publik sebanyak 30,6033 persen. Kepemilikan saham publik terendah adalah sebesar 3,38 persen dan kepemilikan saham publik tertinggi sebesar 75,14 persen. 
Uji statistik deskriptif variabel profitabilitas yang diukur dengan Return On Asset (ROA) menunjukkan rata-rata sebesar 0,0527 atau 5,27 persen. Hal ini berarti bahwa perusahaan sampel rata-rata mampu mendapatkan laba bersih sebesar 5,27 persen dibanding dengan total aset yang dimiliki perusahaan. ROA terendah adalah 0,0003 atau 0,03 persen dan ROA tertinggi adalah 0,26 atau 26 persen.

Uji statistik deskriptif variable pengungkapan CSR yang yang diukur dengan 91 item menunjukkan rata-rata sebesar 0,1514 atau 15,14 persen. Hal ini berarti bahwa rata-rata perusahaan sampel telah mengungkapkan sebesar 15,14 persen dari 91 pengungkapan sosial maksimal. Pengungkapan CSR terendah adalah sebesar 0,08 atau 8 persen dan pengungkapan CSR terbesar mencapai 0,27 atau 27 persen.

Tabel 2. Statistik Deskriptif

\begin{tabular}{|c|c|c|c|c|c|}
\hline & $\mathbf{N}$ & Min & Max & Mean & Std. Dev \\
\hline Publik & 90 & 3.38 & 75.15 & 30.6033 & 18.63880 \\
\hline ROA & 90 & .0003 & .26 & .0527 & .05114 \\
\hline CSR & 90 & .08 & .27 & . 1514 & .04513 \\
\hline $\begin{array}{l}\text { Valid N } \\
\text { (listwise) }\end{array}$ & 90 & & & & \\
\hline
\end{tabular}

Tabel 3. Dummy Variable

\begin{tabular}{|c|c|c|c|c|}
\hline & Freq. & Percent & Valid Percent & Cummulative Percent \\
\hline .00 & 6 & 6.7 & 6.7 & 6.7 \\
\hline Valid $\quad 1.00$ & 84 & 93 & 93 & 93 \\
\hline Total & 90 & 100.0 & 100.0 & 100.0 \\
\hline
\end{tabular}

Sumber : data diolah, 2019.

Variable media yang diukur dengan dummy variabel menunjukkan sebesar 93,3 persen perusahaan sampel memiliki media website. Hal ini berarti bahwa sebanyak 93,3 persen perusahaan sampel memiliki website untuk mempublikasikan laporan keuangan perusahaan.

Tabel 4. Analisis Regresi Berganda

\begin{tabular}{|c|c|c|c|c|c|}
\hline & \multirow{2}{*}{ Model } & \multicolumn{2}{|c|}{ Unstandardized Coefficients } & \multirow{2}{*}{$\mathbf{t}$} & \multirow{2}{*}{ Sig. } \\
\hline & & B & Std. Error & & \\
\hline \multirow[t]{4}{*}{1} & (Constant) & .096 & .018 & 5.260 & .000 \\
\hline & Publik & .001 & .000 & 2.828 & .006 \\
\hline & ROA & -.030 & .008 & -.340 & .734 \\
\hline & Media & .038 & .018 & 2.037 & .045 \\
\hline \multicolumn{3}{|c|}{$\begin{array}{l}\text { R Square }=.168 \\
\text { Adj. } \mathrm{R} \text { Square }=.139 \\
\text { Durbin-Watson }=2.013\end{array}$} & & \multicolumn{2}{|c|}{$\begin{array}{l}\text { F hitung }=5.770 \\
\text { Sig. } F=.001\end{array}$} \\
\hline
\end{tabular}

Sumber : data diolah, 2019.

Adjusted koefisien determinasi (Adjusted $\mathrm{R}^{2}$ ) merupakan nilai untuk mengevaluasi model regresi mana yang terbaik atau melihat seberapa besar variasi terikat $(Y)$ ditentukan oleh variabel bebas $(\mathrm{X})$. Analisis regresi linier berganda menunjukkan bahwa nilai Adjusted $R^{2}$ sebesar 0,139 yang artinya variasi variabel $Y$ ditentukan hanya sebesar 13,9 persen oleh 
variabel bebas dalam model penelitian ini, sedangkan sisanya sebesar 86,1 persen ditentukan oleh variable-variabel lain yang tidak masuk dalam model penelitian ini.

Uji simultan (Uji F) digunakan untuk menunjukkan apakah variabel bebas secara bersama-sama memiliki pengaruh terhadap variabel terikat. Berdasarkan analisis regresi linier berganda menunjukkan bahwa secara simultan variabel bebas yang terdiri dari variabel kepemilikan saham publik (X1); variabel profitabilitas (X2); dan variabel media (X3) secara simultan berpengaruh terhadap variabel terikat yaitu pengungkapan CSR $(\mathrm{Y})$. Analisis tersebut didasarkan pada hasil pengujian regresi yang menunjukkan nilai sig 0,001 $<0,05$ sehingga Ho ditolak yang berarti secara simultan semua variabel bebas berpengaruh terhadap variabel pengungkapan CSR $(Y)$.

Analisis regresi linier berganda menunjukkan bahwa variabel kepemilikan saham publik dan variabel media berpengaruh positif terhadap pengungkapan CSR. Hal tersebut dapat dilihat dari nilai signifikansi variabel kepemilikan saham publik sebesar 0,006 0,05 maka Ha diterima. Selanjutnya nilai signifikansi variabel media sebesar 0,045<0,05 maka Ha diterima. Sedangkan nilai signifikansi variabel profitabilitas sebesar 0,734 $>0,05$ dengan demikian maka Ha ditolak.

Pengaruh Struktur Kepemilikan Saham Publik terhadap CSR Pada Perusahaan Property dan Real Estate yang Terdaftar di BEI tahun 2016-2018. Berdasarkan hasil analisis, variabel kepemilikan saham publik berpengaruh signifikan terhadap pengungkapan CSR pada perusahaan Property dan Real Estate yang terdaftar di Bursa Efek Indonesia periode 2016-2018. Temuan penelitian ini memperkuat teori stakeholder. Stakeholder merupakan hal yang berhubungan erat terhadap tanggung jawab sosial. Stakeholder merupakan pihak-pihak yang berhubungan dan dapat mempengaruhi atau dipengaruhi oleh proses pencapaian tujuan suatu organisasi. Teori stakeholder menjelaskan perusahaan yang sahamnya dimiliki oleh publik akan melakukan pengungkapan tanggung jawab sosial yang lebih besar daripada perusahaan yang sahamnya tidak dikuasai oleh publik (Rahayuet al., 2015).

Hal ini mendukung Sriayu et al. (2013) dan Rahayu et al. (2015) bahwa kepemilikan saham publik berpengaruh signifikan terhadap pengungkapan tanggung jawab sosial. Perusahaan yang sahamnya dikuasai publik lebih banyak, maka artinya investor telah memberikan kepercayaan kepada perusahaan sehingga untuk menjaga kepercayaan tersebut, perusahaan akan semaksimal mungkin mengungkapkan segala kegiatan yang ada di perusahaannya. Salah satu pengungkapan tersebut adalah kegiatan tanggung jawab sosial perusahaan.

Berbeda dengan temuan Indraswari \& Astika (2015) dan Nur \& Priantinah (2012) menunjukan bahwa kepemilikan saham publik tidak berpengaruh terhadap pengungkapan tanggung jawab sosial. Dengan demikian mereka menyimpulkan jika besar atau kecilnya kepemilikan saham publik belum tentu akan mempengaruhi pengungkapan tanggung jawab sosial perusahaan tersebut.

Pengaruh Profitabilitas terhadap CSR Pada Perusahaan Property dan Real Estate yang Terdaftar di BEI tahun 2016-2018. Berdasarkan hasil analisis, variabel profitabilitas tidak berpengaruh signifikan terhadap pengungkapan CSR pada perusahaan Property dan Real Estate yang terdaftar di Bursa Efek Indonesia periode 2016-2018. 
Pengaruh Kepemilikan Saham Publik, Profitabilitas, dan ...

Silvia Debora Hitipeuw, Yeni Kuntari, Triani

Ghozali \& Chariri (2007) menjelaskan bahwa teori legitimasi sangat bermanfaat dalam menganalisis perilaku organisasi, karena teori legitimasi adalah hal yang paling penting bagi organisasi, batasan-batasan yang ditekankan oleh norma-norma dan nilai-nilai sosial dan reaksi terhadap batasan tersebut mendorong pentingnya analisis perilaku organisasi dengan memperhatikan lingkungan. Perusahaan dengan profitabilitas tinggi belum tentu melakukan pengungkapan sosial yang lebih karena perusahaan lebih berorientasi laba. Hal ini didukung dengan argumentasi bahwa pada saat perusahaan mencapai tingkat profitabilitas tinggi, manajemen akan lebih tertarik untuk memfokuskan pengungkapan informasi kinerja keuangan perusahaan mengenai pencapaian laba perusahaan. Pihak manajemen menganggap tidak perlu menginformasikan hal-hal yang dapat mengganggu informasi tentang kesuksesan keuangan perusahaan (Indraswari et al., 2017). Profitabilitas perusahaan berkaitan dengan teori legitimasi karena jika keuntungan yang didapat perusahaan besar akan mendapatkan pengungkapan informasi yang lebih luas. Apabila perusahaan ingin tetap hidup untuk dapat tumbuh dan berkembang, maka perusahaan harus memperoleh laba. Profitabilitas perusahaan jika dihubungan dengan CSR yaitu perusahaan akan mendapatkan keuntungan yang besar berupa nilai dan dukungan penuh dari masyarakat.

Penelitian ini mendukung temuan Sriayu et al. (2013) dan Nur \& Priantinah (2012). Hasil penelitian ini juga tidak berhasil mendukung teori legitimasi bahwa profitabilitas berpengaruh negatif terhadap pengungkapan tanggung jawab sosial perusahaan. Hal ini didukung dengan argumentasi bahwa ketika perusahaan memiliki laba yang tinggi, perusahaan tidak perlu melaporkan hal-hal yang mengganggu informasi tentang suksesnya keuangan perusahaan. Sedangkan pada saat tingkat profitabilitas rendah, mereka berharap para pengguna laporan keuangan akan membaca good news kinerja perusahaan, misalnya dalam lingkup sosial dan dengan demikian investor akan berinvestasi di perusahaan tersebut. Dengan demikian dapat dikatakan bahwa setiap peningkatan atau penurunan profitabilitas tidak mempengaruhi tingkat pengungkapan tanggung jawab sosial perusahaan.

Berbeda dengan Sari (2012) dan Indraswari et al. (2015) yang menyatakan profitabilitas berpengaruh positif terhadap pengungkapan tanggung jawab sosial. Sehingga semakin tinggi tingkat profitabilitas maka semakin besar tingkat pengungkapan CSR yang dilakukan perusahaan.

Pengaruh Media terhadap CSR Pada Perusahaan Property dan Real Estate yang Terdaftar di BEI tahun 2016-2018. Berdasarkan hasil analisis, variabel media berpengaruh signifikan terhadap pengungkapan CSR pada perusahaan Property dan Real Estate yang terdaftar di Bursa Efek Indonesia periode 2016-2018. Perusahaan harus mempunyai kapasitas untuk memenuhi kebutuhan stakeholders dan berkomunikasi dengan stakeholders secara efektif jika perusahaan ingin mendapat kepercayaan dan legitimasi melalui aktivitas CSR. Fungsi komunikasi menjadi sangat penting dalam manajemen CSR. Perusahaan dapat mengungkapkan aktivitas CSR melalui berbagai media. Komunikasi melalui media akan meningkatkan reputasi perusahaan di mata masyarakat (Nur \& Priantinah, 2012).

Penelitian ini mendukung Kristi (2013) dan Pakpahan (2018) bahwa variabel media berpengaruh terhadap pengungkapan tanggung jawab sosial. Hal ini menunjukkan semakin 
tinggi media exposure perusahaan maka semakin meningkat reputasi perusahaan di mata masyarakat sehingga pengungkapan tanggung jawab sosial juga semakin meningkat.

Berbeda dengan Rahayu et al. (2015) dan Nur et al. (2012) yang menemukan bahwa pengungkapan media tidak memiliki pengaruh signifikan terhadap pengungkapan tanggung jawab sosial. Alasan yang dapat menjelaskan hal ini adalah karena website perusahaan telah digunakan sebagai sarana komunikasi pelaporan keuangan, walaupun keberadaan pelaporan keuangan dalam website yang dibuat oleh perusahaan belum terdapat kuantitas dan kualitas yang terstandarisasi antar perusahaan. Selain itu, mengingat pesatnya penggunaan internet di kalangan masyarakat, pemanfaatan website perusahaan untuk mengkomunikasikan program CSR juga harus dipertimbangkan risiko yang mengikutinya, seperti adanya risiko plagiasi ataupun yang dapat membuat citra perusahaan tidak baik.

\section{KESIMPULAN}

Berdasarkan dari hasil analisis dan pembahasan dapat disimpulkan sebagai berikut :

1. Kepemilikan Saham Publik dan Media secara parsial berpengaruh positif signifikan terhadap pengungkapan CSR pada perusahaan Property dan Real Estate yang terdaftar di Bursa Efek Indonesia 2016-2018.

2. Profitabilitas tidak berpengaruh terhadap Pengungkapan CSR pada perusahaan Property dan Real Estate yang terdaftar di Bursa Efek Indonesia 2016-2018.

3. Kepemilikan Saham Publik, Profitabilitas, dan Media secara simultan berpengaruh positif signifikan terhadap Pengungkapan CSR pada perusahaan Property dan Real Estate yang terdaftar di Bursa Efek Indonesia 2016-2018.

Hasil penelitian ini menunjukan variabel Profitabilitas (ROA) tidak berpengaruh signifikan terhadap Pengungkapan CSR pada perusahaan Property dan Real Estate. Hal ini mengindikasikan bahwa perusahaan dengan profitabilitas tinggi belum tentu lebih banyak melakukan pengungkapan tanggung jawab sosial, di mana ketika profitabilitas perusahaan tinggi, manajemen perusahaan lebih tertarik untuk memfokuskan pengungkapan informasi kinerja keuangan perusahaan. Perusahaan dengan tingkat pertumbuhan yang tinggi cenderung lebih memilih menggunakan biaya-biaya untuk kegiatan produksi sehingga dapat meningkatkan penjualan dan meningkatkan keuntungan perusahaan, dibandingkan menggunakannya untuk kegiatan terkait aktivitas sosial, sebab investor dianggap lebih berorientasi pada keuntungan perusahaan. Dengan demikian dapat dikatakan bahwa setiap peningkatan atau penurunan profitabilitas tidak mempengaruhi tingkat pengungkapan tanggung jawab sosial perusahaan.

Untuk penelitian selanjutnya direkomendasikan menggunakan periode pengamatan yang lebih lama agar dapat memprediksi hasil penelitian jangka panjang serta menganalisis objek perusahaan terdaftar Bursa Efek Indonesia yang lebih luas daripada sektor property dan real estate. Penelitian selanjutnya juga dapat menggunakan atau menambah variabel penelitian lain yang tidak digunakan dalam penelitian ini seperti nilai perusahaan, kinerja keuangan dan lain-lain. 
Pengaruh Kepemilikan Saham Publik, Profitabilitas, dan ...

Silvia Debora Hitipeuw, Yeni Kuntari, Triani

\section{DAFTAR PUSTAKA}

Alnajjar, F.K. (2000). Determinants of Sosial Responsibility Disclosures of Application of Content Analysis. Advances in Environmental Accounting \& Management, 1, pp.163200.

Badjuri, A. (2011). Faktor-Faktor Fundamental, Mekanisme Coorporate Governance, Pengungkapan Coorporate Sosial Responsibility. Jurnal Dinamika Keuangan Dan Perbankan.

Franita, R. (2018). Mekanisme Good Corporate Governace dan Nilai Perusahaan. Medan: Lembaga Penelitian dan Penulisan IImiah Aqli.

Gamerschlag, R., Möller, K. \& Verbeeten, F. (2011). Determinants of Voluntary CSR Disclosure: Empirical Evidence from Germany. Review of Managerial Science, 5(2), pp.233-262.

Giannarakis, G., (2014). Corporate Governance and Financial Characteristic Effects on The Extent of Corporate Sosial Responsibility Disclosure. Sosial Responsibility Journal, 10(4), pp.569-590.

Ghozali, I. (2011). Aplikasi Analisis multivariate dengan Program IBM SPSS 21. Semarang: Badan Penerbit Fakultas Ekonomi Universitas Diponegoro.

Ghozali, I. \& Chariri, A. (2007). Teori Akuntansi. Semarang : Badan Penerbit Fakultas Ekonomi Universitas Diponegoro.

Haniffa, R.M. \& Cooke, T.E. (2005). The Impact of Culture and Governance on Corporate Sosial Reporting. Journal of Accounting and Public Policy, 24(5), pp.391-430.

Harmoni, A. (2010). Media Richness Theory dan Potensi Website Sebagai Media Komunikasi CSR oleh Perusahaan. Jurnal Ekonomi Bisnis, 15(1), pp. 9-17.

Hery. (2017). Kajian Riset Akuntansi. Jakarta: Gramedia.

Indraswari, G. A. D. \& Astika, I. B. P. A. (2015). Pengaruh Profitabilitas, Ukuran Perusahaan, dan Kepemilikan Saham Publik Terhadap Pengungkapan CSR. E-Jurnal Akuntansi Universitas Udayana.

Indriantoro, N. \& Supomo, B. (2002). Metodologi Penelitian Bisnis Untuk Akuntansi dan Manajemen. Edisi Pertama, Yogyakarta : BPFE Universitas Gadjah Mada.

Julekhah, F. \& Rahmawati, E. (2019). Pengaruh Media Exposure, Sensitivitas Industri, Kepemilikan Asing, Kepemilikan Publik dan Profitabilitas Terhadap Environmental Disclosure dan Dampaknya Terhadap Nilai Perusahaan. Reviu Akuntansi dan Bisnis Indonesia, 3(1), pp. 50-66.

Kasmir. (2016). Analisis Laporan Keuangan. Jakarta : PT Raja Grafindo Persada.

Kristi, A. A. (2013). Faktor-Faktor Yang Mempengaruhi Pengungkapan Corporate Sosial Responsibility Pada Perusahaan Publik Di Indonesia. Skripsi. Fakultas Ekonomi dan Bisnis, Universitas Brawijaya.

Kuncoro, M. (2003). Metode Riset untuk Bisnis \& Ekonomi. Jakarta: Erlangga.

Na'im, A. \& Rakhman, F. (2000). Analisis Hubungan Antara Kelengkapan Pengungkapan Laporan Keuangan dengan Struktur Modal dan Tipe Kepemilikan Perusahaan. Jurnal Riset Akuntansi Indonesia, 15.

Lako, A. (2011). Dekonstruksi CSR dan Reformasi Paradigma Bisnis dan Akuntansi. Jakarta: Erlangga.

Karina, L. A. D. \& Yuyetta, E. N. A. (2013). Analisis Faktor-Faktor Yang Mempengaruhi Pengungkapan CSR. E-Journal of Accounting, 2(2).

Morissan. (2015). Periklanan Komunikasi Pemasaran Terpadu. Jakarta: Pernada Media Group.

Muttakin, M.B., Khan, A. \& Subramaniam, N. (2015). Firm Characteristics, Board Diversity And Corporate Sosial Responsibility. Pacific Accounting Review, 27(3), pp.353-372. 
Purwanto, A. (2011). Pengaruh Tipe Industri, Ukuran Perusahaan, Profitabilitas Terhadap Corporate Sosial Responsibility. Jurnal Akuntansi \& Auditing Universitas Diponegoro, 8(1), pp.1-94.

Rahayu, P. \& Anisyukurlillah, I. (2015). Pengaruh Kepemilikan Saham Publik, Profitabilitas dan Media Terhadap Pengungkapan Tanggung Jawab Sosial. Jurnal Akuntansi.

Rahman, R. (2009). Corporate Sosial Responsibility : Antara Teori dan Kenyataan. Yogyakarta: Media Pressindo.

Sari, R. A. (2012). Pengaruh Karakteristik Perusahaan Terhadap Corporate Sosial Responsibility Disclosure Pada Perusahaan Manufaktur Yang Terdaftar Di Bursa Efek Indonesia. Jurnal Nominal, 1(1), pp. 124-140.

Sriayu, G. A. P. W. \& Nimba, N. P. S. H. (2013). Pengaruh Karakteristik Perusahaan Terhadap Corporate Sosial Responsibility Disclosure. E-Jurnal Akuntansi Universitas Udayana, 5(2), pp. 326-344.

Sugiyono. (2001). Metode Penelitian Bisnis. Bandung : Alfabeta.

Suharto, (2010). CSR \& Comdev : Investasi Kreatif Perusahaan Di Era Globalisasi, Bandung : Alfabeta.

Undang-Undang RI No. 40 Tahun 2007.

Wijaya, M. (2012). Faktor-Faktor yang Mempengaruhi Pengungkapan Tanggungjawab Sosial Pada Perusahaan Manufaktur yang Terdaftar di Bursa Efek Indonesia. Jurnal IImiah Mahasiswa Akuntansi, 1(1). 